nest containing a Cow-bunting's egg, over which was built another nest containing six eggs of the Goldfinch.

In the nest of the second form the walls are much thinner, and the general form and structure much resemble a Vireo's nest. These beautiful frail structures, however, are much better adapted to their position on the ends of hranches than the thick nests would be if placed in that position.

The eggs are from three to six in mumber, most commonly five, blue, unspotted, save in the instance of two sets evidently belonging to the same pair of birds, which I found, one set in 1890, the other in '91, in the same tree. The eggs were finely spotted with reddish brown forming a wreath around the larger end. I have never heretofore seen an instance of spotted eggs of the Goldfinch noted in ornithological publications, and I believe their occurrence is somewhat uncommon. Paul Van Rtperr.

\section{Physical Chemistry at the Columbian Congress.}

THe recent doctrines of chemical energy are pushing towards the front. The opening paper on physical chemistry was presented to the Congress by the writer of this report, who called attention to the valuable results arising from "the cross-fertilization of the sciences." The physical properties of substances have long been studied, under the name of chemical physics; such data are indispensable in chemical analysis, technology, etc. - But, with transposition of the terms, we find more attention given to the properties of energy itself, and to the conditions of equilibrium, and of rapid or slow change. These generalizations promise to be most fruitful of results, and deserving of general recognition in our universities.

The second paper, "on chemical energy," was contributed by Professor Ostwald, of Leipsic, who is indefatigable, both in research and in expounding the progress of science. The two factors, capacity and intensity, are discussed and illustrated in this paper, with great perspicuity. Capacity is proportional to the mass; for two tons of coal, by combustion, will yield twice as much heat as one ton. To estimate the intensity, on the other hand, we may remember that heat conduction always implies some difference in heat intensity; so, a chemical transformation implies greater intensity of chemical energy in the reacting bodies than in the reaction products, under comparable conditions. A "chemometer" anologous to thermometer, though not yet complete, is not wholly unknown. Emphasis is given to the theorem, "two potentials which individually are equal to a third are equal to each other," with important deductions therefrom; and catalytic bodies are discussed in relation to the acceleration of chemical change.

A third paper, by Prof. J. E. Trevor, of Ithaca, states the fundamental equations of equilibrium, for three leading cases, and presents some extended mathematical deductions.

Three other communications, assigned to this section, are of more varied character. Prof. E. W. Morley stated by request some of his results in determining the atomic weight of oxygen, with remarkably close agreement, at about 15.88; but the work is still in progress.

Professor Lunge, of Zurich (whose genial presence added much to the interest of the Congress) described apparatus for promoting the interaction of liquids and gases. Perforated earthenware plates, of special form, are so placed as to promote contact of the reacting substances, -as in sulphuric acid manufacture.

Prof. T. H. Norton communicated a paper from Professor Orndorff, illustrating by models the stereochemistry of paraldehyde and metaldehyde $\left(\mathrm{C}_{2} \mathrm{H}_{4}\right)_{3}$. The three methyl groups are assumed in one case to be all on one side of the plane of the carbon-oxygen ring; and in the other case to be distributed on both sides.

ROBERT B. WARDER.

HowARD UNIVERSity, WASHINGTON D. C.

Great Horned OWLS in Confinement.

WHILE collecting in some dense pine woods early in April, r886, I saw a great horned ow1 about every day which flew from a nest in a pine tree. This tree was the tallest of its kind in the vicinity, and the nest was at least seventy-five feet from the ground. Thinking I might secure its eggs or young, I climbed the tree and found, much to my disgust, that the bird used the nest only as a roosting place.

By patient watching and hunting I discovered its nest April r9, in a large chestnut tree. It was composed of coarse sticks and was lined with feathers and down from the parent bird, and had the appearance of having been a deserted hawk's nest.

Here I found two young birds which were covered with down and were about half grown. Their tail and wing feathers were just starting out. They tried to defend themselves like an adult bird by keeping up a continual hissing and blowing sound, and at the same time snapping their bills and opening and closing their eyes. I noticed that they occasionally made a low, murmuring sound, and also a louder and harsher note, which they make now when hungry.

In the nest with them were two half-eaten fish, Catostomus communis, and the hinder portion of two brown rats. When in confinement, a week or two later, they ate voraciously, and one day I offered one a dead mourning dove. It seized it head first, and in a very few minutes succeeded in swallowing it entire, except the tips of its tail feathers, which protruded from its mouth. I expected then it would fall a victim to its gluttony, but within a very short time the tail feathers had disappeared, and it remained very quiet for two or three hours, after that it showed no discomfort whatever from its meal.

April 27 they could walk quite well, and about June I 5 the feathers started out on the head of the smaller bird, which I believe to be a male, although it was by far the larger when taken from the nest.

The feathers on the larger, wor female bird, did not appear until July 4 , and at this date the wing and the tail feathers on both were full grown. After this time they consumed but a small portion of the food they formerly did, although they occasionally ate voraciously. They seem to prefer rats, mice, birds and are quite partial to beef.

About the middle of October the larger, and what I believe to be the female bird, began to hoot, but not very loud. This is performed by the bird standing at its full height, with its ear-tufts (which were fully developed October $\mathrm{r}$ ) erect, but slightly slanting. backward, and swelling out its throat it gives utterance to the notes, "waugh ho ho ho ho."

They recognize all strangers, and appear afraid of dogs, horses and cows, but always show fight and act on the defensive. Their way of showing fight is tc lower their head and tail, and spread their wings to nearly their full extent, but arching them so as to protect their body, and at the same time utter a peculiar blowing or hissing sound, accompanied with a snapping of their bills.

They have been confined in a large cage for over seven years, and during this time have showed no inclination to breed, and when not disturbed have made no attempts to escape, but sit quietly on their perches through the day. Just after dark they move about considerably. 
Their "hootings" seem to be confined to no especial season of the year, but can be heard almost any night, and are quite noisy moonlight nights.

As they grow older they consume less food, and are not fed oftener than every other day. They are strong and vigorous, and, as a proof of their muscular powers, I once saw the female lift a dead turkey, which weighed no less than eight pounds, bodily, from the ground.

Their sense of hearing is especially good; the least noise always attracts their attention. As for their eyesight, in broad daylight no birds could be better, as I have frequently noticed them looking at birds, which were flying over, at very great heights, on very clear and bright days.

They have never made any attempts to breed whatever, nor has either one shown any affection for the other, although they seem to be on the best of terms, except when eating they occasionally have a scrimmage over a piece of meat.

Willard E. Treat.

East Hartford, Conn.

\section{BOOK-REVIEWS.}

An Introduction to the Study of the Dependent, Defective and Delinquent Classes. By Charles Richmond Henderson. Boston: D. C. Health \& Co. $12^{\circ}, 272$ p. $\$ 1.50$.

THe author of this book has been for more than twenty years a student of the classes of which it treats, and has been connected with many agencies for their improvement and reformation. He has not only been a close observer of those classes and of the methods that society has adopted for dealing with them, but is also widely read in the literature of the subject; and his book shows that he has read with discriminating judgment and to good purpose. Mr. Henderson is assistant professor of social science in the University of Chicago, and evidently had his pupils in mind in preparing this book; for it is not designed for those professionally engaged with the dependent and criminal classes, but rather for the educated citizen, who only wants a general knowledge of the subject. The book is divided into three parts, corresponding to the three classes of which it treats; and these parts are again divided and sub-divided into chapters and sections; the work of division and systematization being carried, as it seems to us, to excess, since it gives the treatise too formal a character without adding to its scientific value. The author expresses himself plainly and with judicial temper, and has no hobbies, scientific or practical, to cloud his judgment.

The part of the book relating to the defective classes, such as the insane, the blind and others, is quite short, the author evidently feeling that the treatment of those classes is rather out of the range of social science. The chapters concerning pauperism, its causes and remedies are good; and though they contain nothing new or striking, they present the best views now prevalent and also the methods now employed by the leading nations in their treatment of the poor. But by much the larger portion of the volume is devoted to the criminal classes, with special chapters on the criminal type and on the causes of crime and the best methods of dealing with it. Mr. Henderson, though evidently familiar with the Italian writers and others who regard crime as similar to disease and as largely due to biological causes, does not share their views; but maintains that the source of crime is in the moral nature, and consequently that remedies and preventives must be such as will have a moral effect. At the same time he by no means overlooks the fact that criminals are of different kinds, and that in the case of some of them poverty and other unfavorable circumstances have been contributive causes of their crime. We commend the book as a convenient introduction to the subject with which it deals.

Alternating Currents of Electricity: By Gisbert Kapp, C. E., M. I. C. E., M. I. E. E., With an introduction by William Stanley, Jr. New York: W. J. Johnston Co.

Alternating current work has been developed so recently that there are a large number of electrical engineers in the profession who finished their technical education before the subject had attracted much attention. Of these a goodly number have since worked up the subject, among them being some of the best-known specialists in that branch.

\begin{tabular}{|c|c|c|}
\hline \multirow{2}{*}{ 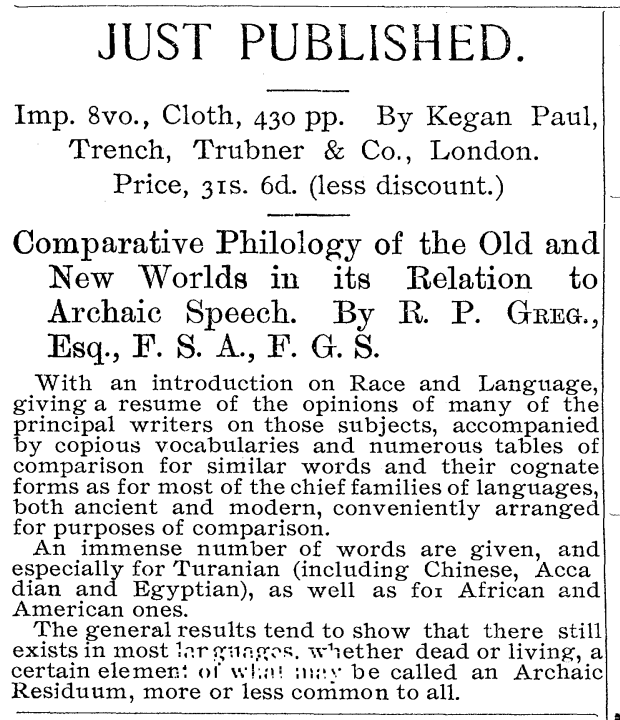 } & & \multirow{2}{*}{ 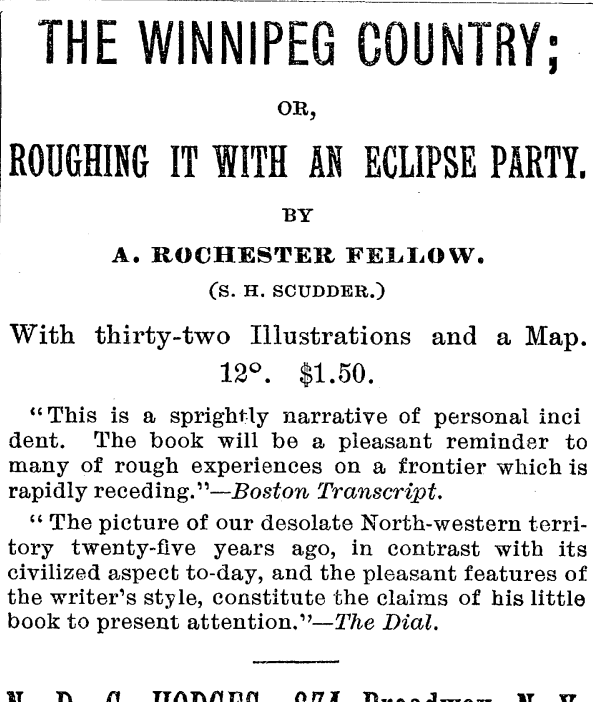 } \\
\hline & 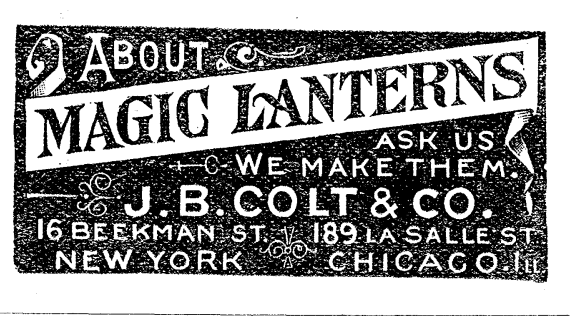 & \\
\hline 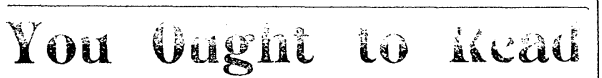 & 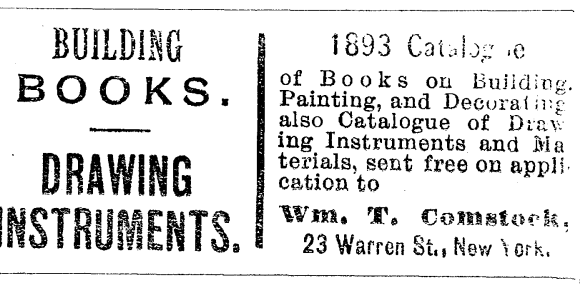 & \\
\hline & 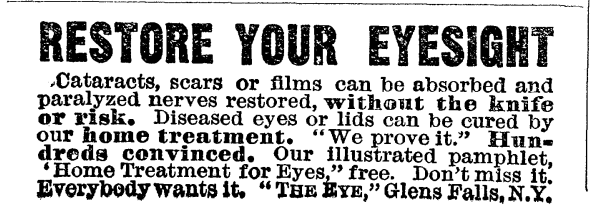 & \\
\hline
\end{tabular}

